\title{
Intraoperative Flurbiprofen Treatment Alters Immune Checkpoint Expression in Patients Undergoing Elective Thoracoscopic Resection of Lung Cancer
}

\author{
Ji-cheng Hu ${ }^{a}$ Xiao-qing Chai ${ }^{a}$ Di Wang ${ }^{a}$ Shu-hua Shu ${ }^{a}$ Costan G. Magnussen ${ }^{a-c} \quad$ Li-xia Xie $^{a}$ \\ Shan-shan $\mathrm{Hu}^{\mathrm{b}, \mathrm{d}}$ \\ ${ }^{a}$ Department of Anesthesiology, Anhui Provincial Hospital, First Affiliated Hospital of USTC, Division of Life Science \\ and Medicine, University of Science and Technology of China, Hefei, PR China; ${ }^{\mathrm{b}}$ Menzies Institute for Medical Research, \\ University of Tasmania, Hobart, TAS, Australia; ${ }^{C}$ Research Centre of Applied and Preventive Cardiovascular Medicine, \\ University of Turku, Turku, Finland; ${ }^{d}$ Institute of Clinical Pharmacology, University of Science and Technology of China, \\ Hefei, PR China
}

\section{Highlights of the Study}

- $\mathrm{CD} 4^{(+)}$and $\mathrm{CD} 8^{(+)} \mathrm{T}$ cells in the peripheral blood of lung cancer patients express higher levels of PD-1, which indicates a poorer clinical outcome.

- PD-1 expression levels were markedly induced in the peripheral blood of lung cancer patients following surgery.

- Perioperative administration of flurbiprofen attenuated the postoperative increase in PD-1 levels on circulating $\mathrm{CD}^{(+)} \mathrm{T}$ cells for up to $72 \mathrm{~h}$.

\section{Keywords}

Immune cells · Lung cancer · Flurbiprofen · Programmed death 1

\section{Abstract \\ Objectives: This study aimed to determine the effect of in- traoperative administration of flurbiprofen on postoperative levels of programmed death 1 (PD-1) in patients undergoing thoracoscopic surgery. Materials and Methods: In this pro- spective double-blind trial, patients were randomized to re- ceive intralipid (control group, $n=34,0.1 \mathrm{~mL} / \mathrm{kg}$, i.v.) or flur- biprofen axetil (flurbiprofen group, $n=34,50 \mathrm{mg}$, i.v.) before induction of anesthesia. PD-1 levels on T cell subsets, inflam- mation, and immune markers in peripheral blood were ex- amined before the induction of anesthesia $\left(T_{0}\right)$ and $24 \mathrm{~h}\left(\mathrm{~T}_{1}\right)$, $72 \mathrm{~h}\left(\mathrm{~T}_{2}\right)$, and 1 week $\left(\mathrm{T}_{3}\right)$ after surgery. A linear mixed model}

\section{KARGER}

karger@karger.com www.karger.com/mpp

(c) 2019 The Author(s) Published by S. Karger AG, Basel

Karger

Open access

This is an Open Access article licensed under the Creative Commons Attribution-NonCommercial-4.0 International License (CC BY-NC) (http://www.karger.com/Services/OpenAccessLicense), applicable to the online version of the article only. Usage and distribution for commercial purposes requires written permission. was used to determine whether the changes from baseline values $\left(\mathrm{T}_{0}\right)$ between groups were significantly different. $\boldsymbol{R} \boldsymbol{e}$ sults: The increases in the percentage of PD- $1^{(+)} \mathrm{CD} 8^{(+)} \mathrm{T}$ cells observed at $T_{1}$ and $T_{2}$ in the control group were higher than those in the flurbiprofen group $\left(\mathrm{T}_{1}: 12.91 \pm 1.65\right.$ vs. $7.86 \pm$ $5.71 \%, p=0.031 ; \mathrm{T}_{2}: 11.54 \pm 1.54$ vs. $\left.8.75 \pm 1.73 \%, p=0.004\right)$, whereas no differences were observed in the changes in the percentage of PD- $1^{(+)} C D 4^{(+)} T$ cells at $T_{1}$ and $T_{2}$ between the groups. Moreover, extensive changes in the percentage of lymphocyte subsets and inflammatory marker concentrations were observed at $T_{1}$ and $T_{2}$ after surgery and flurbiprofen attenuated most of these changes. Conclusions: Perioperative administration of flurbiprofen attenuated the postoperative increase in PD-1 levels on $\mathrm{CD}^{(+)}$T cells up to $72 \mathrm{~h}$ after surgery, but not after this duration. The clinical relevance of changes in PD-1 levels to long-term surgical outcome remains unknown.

(c) 2019 The Author(s)

Published by S. Karger AG, Basel

Xiao-qing Chai and Di Wang

Department of Anesthesiology, Anhui Provincial Hospital

First Affiliated Hospital of USTC, Division of Life Science and Medicine

University of Science and Technology of China, Lu Jiang Road, Lu Yang District

Hefei, Anhui 230001 (China)

E-Mail xiaoqingchai@163.com and wangdi@ahmu.edu.cn 


\section{Introduction}

Lung cancer is a major cause of cancer-related deaths globally and approximately $80 \%$ of lung cancers occur as non-small cell lung cancer (NSCLC) [1-3]. Some wellestablished immune-checkpoint molecules expressed on activated T cells, such as programmed death 1 (PD-1 or CD279) and cytotoxic T lymphocyte-associated antigen 4 (CLTA-4 or CD152), functionally suppress T-cell-mediated immunity against tumors and are considered a hallmark of exhausted T cells following persistent stimulation with tumor antigens [4-8]. Increasing evidence indicates that higher levels of immune-checkpoint molecules predict poorer outcomes in cancer patients $[9,10]$. Furthermore, immune-checkpoint blockade (e.g., antiPD-1 therapy) elicits persistent and significant therapeutic responses in multiple tumor types, including lung cancer $[1,11-16]$. However, it remains unclear whether perioperative use of analgesic drugs can directly influence these immune-checkpoint molecules in cancer patients undergoing surgery.

Interestingly, PD-1 and its ligands are markedly inducible by cyclooxygenase (COX) enzymes and downstream prostaglandins (PGs), which are prominent tumor-sustaining inflammatory mediators $[17,18]$. Additionally, nonsteroidalanti-inflammatorydrugs(NSAIDs), which have anti-inflammatory and analgesic activities, including inhibiting COX enzymes, pharmacologically cooperate with anti-PD-1 treatment to increase its efficacy in a preclinical cancer model [19]. In clinical settings, the perioperative administration of flurbiprofen, which is regularly prescribed as a perioperative analgesic, efficiently elicits a short-term increase in the number of innate and adaptive immune cells in postoperative peripheral blood [20]. Since less is known about how NSAIDs synergize with anti-PD-1 therapy in clinical settings, we aimed to determine whether flurbiprofen had a direct effect on postoperative PD-1 levels in circulating $\mathrm{T}$ cell subsets, in patients undergoing elective thoracoscopic resection of NSCLC.

\section{Materials and Methods}

Study Sample

This study was approved by the Biomedical Research Ethics Committee of Anhui Medical University and was registered with the Chinese Clinical Trial Registry (No. ChiCTR-IPR-15006482). All participating patients provided written informed consent. This study was a prospective, double-blind, randomized, controlled clinical trial. Patients were screened at the outpatient department or inpatient wards and underwent randomization between October 15,
2016, and May 10, 2017, at Anhui Provincial Hospital, Hefei, China. Patients were eligible for participation in this study if they met the following criteria: (1) adults undergoing elective thoracoscopic resection of lung cancer, (2) American Society of Anesthesiologists (ASA) status of I-II, (3) aged 40-65 years, and (4) weighing 45-80 $\mathrm{kg}$ for both genders. Patients were excluded if they met any of the following criteria: (1) allergy or contraindication to NSAIDs; (2) history of peptic ulceration; (3) blood coagulation disorder; (4) severe cardiac, hepatic, or renal dysfunction; (5) perioperative blood transfusion; (6) bronchial asthma; (7) current or recent use of radiotherapy, chemotherapy, immune depressant, or glucocorticoid; (8) autoimmune disease or acute inflammation; (9) severe hypertension or diabetes mellitus; (10) pregnancy; (11) use of enoxacin, lomefloxacin, or norfloxacin; and (12) duration of operation <120 min.

\section{Anesthesia and Analgesia}

General anesthesia was induced with $0.05 \mathrm{mg} / \mathrm{kg}$ midazolam, 2 $\mathrm{mg} / \mathrm{kg}$ propofol, and $0.4 \mu \mathrm{g} / \mathrm{kg}$ sufentanil, and double-lumen endobronchial tube insertion was facilitated with $1 \mathrm{mg} / \mathrm{kg}$ rocuronium. The site of the tube was confirmed by fiberoptic bronchoscopy after intubation and by changing the position of the patient prior to surgery. All patients received target-controlled infusion to maintain anesthesia (i.e., propofol and remifentanil with an effective concentration of $3.5-4.5 \mu \mathrm{g} / \mathrm{mL}$ and $2-4 \mathrm{ng} / \mathrm{mL}$, respectively). Patients were mechanically ventilated with suitable ventilation parameters to maintain end-tidal carbon dioxide in the range of 35$45 \mathrm{~mm} \mathrm{Hg}$. In addition, the appropriate depth of anesthesia was monitored using a Narcotrend monitor (MonitorTechnik, Bad Bramstedt, Germany). Postoperatively, all patients received the same regimen of patient-controlled intravenous analgesia with sufentanil $(100 \mu \mathrm{g}$, diluted to a total volume of $100 \mathrm{~mL}$ with $0.9 \%$ sodium chloride). Patient-controlled intravenous analgesia was performed with a loading dose of $2 \mathrm{~mL}$, a background infusion of $2 \mathrm{~mL} / \mathrm{h}$, a bolus of $2 \mathrm{~mL}$, and a lockout time of $15 \mathrm{~min}$.

\section{Intervention and Randomization}

Using a computer-generated random number sequence, patients were allocated in a 1:1 ratio to receive treatment with either flurbiprofen (flurbiprofen axetil, $50 \mathrm{mg}$, i.v.) or placebo (intralipid, $0.1 \mathrm{~mL} / \mathrm{kg}$, i.v.) before the induction of anesthesia. Data collection was performed by an independent researcher who was not involved in the trial. In addition, another researcher was in charge of the preparing the study drugs. The drugs were placed into unmarked syringes, and treatment assignments were concealed in sealed, opaque envelopes. All of which was blinded to patients, anesthetists and other investigators involved in the study. The statistician was unaware of the assignments until all data analyses were completed. In addition, tramadol was administered postoperatively as a rescue analgesic for unbearable pain, when the Visual Analogue Scale score was $\geq 5$.

\section{Outcomes}

Venous blood $(2 \mathrm{~mL})$ was collected from the noninfused peripheral vein before the induction of anesthesia $\left(\mathrm{T}_{0}\right)$ and $24 \mathrm{~h}\left(\mathrm{~T}_{1}\right)$, $72 \mathrm{~h}\left(\mathrm{~T}_{2}\right)$, and 1 week $\left(\mathrm{T}_{3}\right)$ after surgery. Blood samples were preserved in an EDTA anticoagulation tube at $4{ }^{\circ} \mathrm{C}$ for subsequent testing within $24 \mathrm{~h}$. The primary outcomes were counts of circulating $\mathrm{PD}-1^{(+)} \mathrm{CD} 8^{(+)}$and $\mathrm{PD}-1^{(+)} \mathrm{CD} 4^{(+)} \mathrm{T}$ cells at each perioperative time point. The secondary outcomes were the percentages of lymphocyte subsets in peripheral blood mononuclear cells (PBMCs) 


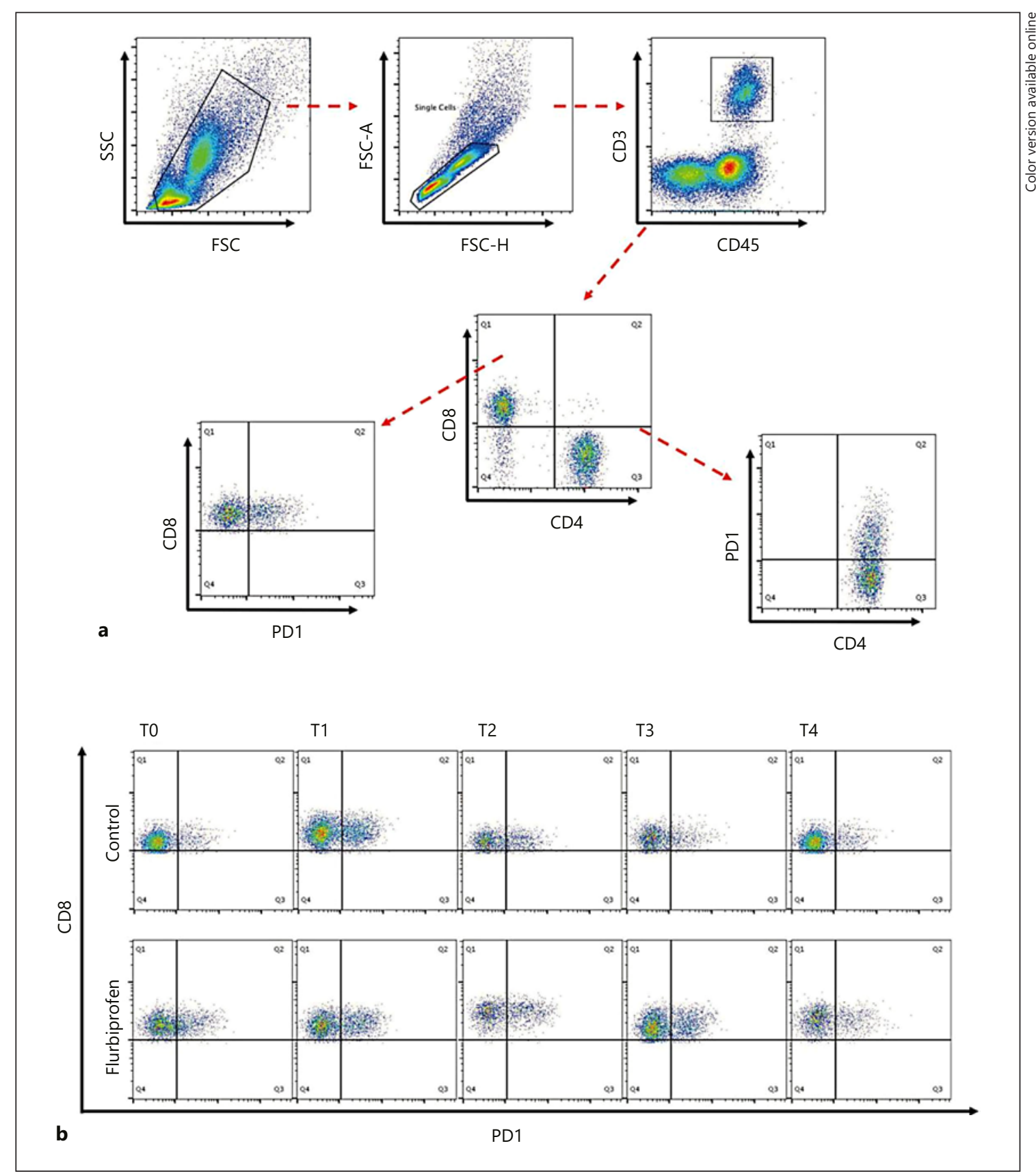

Fig. 1. Flow cytometric analysis results. a Flow cytometric gating strategy and analysis of PD-1 expression on $\mathrm{CD} 45^{(+)} \mathrm{CD}^{(+)} \mathrm{CD}^{(+)}$and $\mathrm{CD} 45^{(+)} \mathrm{CD}^{(+)} \mathrm{CD}^{(+)} \mathrm{T}$-cell populations. $\mathbf{b}$ representative plots of PD-1 expression on the $\mathrm{CD} 8^{(+)} \mathrm{T}$-cell population at different time points. $\mathrm{PD}-1$, programmed death 1 .

and the concentrations of inflammatory markers, including tumor necrosis factor- $\alpha$ (TNF- $\alpha)$, interferon- $\gamma($ IFN- $\gamma)$, interleukin- 6 (IL-6), and C-reactive protein (CRP), in peripheral blood. Moreover, data from full blood count tests, including platelet count, total white blood cell count, hemoglobin concentration, neutrophil count, lymphocyte count, monocyte count, eosinophil count, and basophil count, were tracked simultaneously.

\section{Immune-Checkpoint and Lymphocyte Subset Analyses}

Circulating PD- $1^{(+)} \mathrm{CD} 8^{(+)}$and $\mathrm{PD}-1^{(+)} \mathrm{CD} 4^{(+)} \mathrm{T}$ cell counts were determined as the percentage of total T lymphocytes. The percentages of total $\mathrm{CD}^{(+)} \mathrm{T}$ cells, $\mathrm{CD} 4^{(+)}$helper $\mathrm{T}$ cells, $\mathrm{CD} 8^{(+)}$cytotoxic $\mathrm{T}$ cells, and $\mathrm{CD}^{(-)} \mathrm{CD} 16^{(+)} \mathrm{CD} 56^{(+)} \mathrm{NK}$-cells in PBMCs were measured by flow cytometry (CytoFLEX; Beckman, Brea, CA, USA). PBMCs were separated from peripheral blood by Ficoll-Hypaque density- 
gradient centrifugation. PBMCs were resuspended in $0.2 \mathrm{~mL}$ of phosphate buffered saline $\left(4 \times 10^{6} / 100 \mu \mathrm{L}\right)$ and incubated for $30 \mathrm{~min}$ on ice with the appropriate antibody dilution. The antibodies used in this study were anti-CD45-PercpCy5.5, anti-CD3-FITC, anti-CD8PE, anti-CD4-APC, and anti-PD-1-PE-Cy7 (Biolegend, San Diego, CA, USA). The flow cytometric gating strategy and analysis of $\mathrm{PD}-1$ expression were based on the $\mathrm{CD} 45^{(+)} \mathrm{CD} 3^{(+)} \mathrm{CD} 4^{(+)}$and $\mathrm{CD} 45^{(+)} \mathrm{CD}^{(+)} \mathrm{CD} 8^{(+)} \mathrm{T}$-cell populations (Fig. 1a).

\section{Measurement of Inflammatory Cytokines}

The concentrations of TNF- $\alpha$, IFN- $\gamma$, and IL- 6 were measured by enzyme-linked immunosorbent assay (R\&D Systems, Minneapolis, MN, USA) as per the manufacturer's protocol.

Full Blood Count, Serum Glucose, and CRP Measurement

Full blood count analysis was performed on EDTA peripheral blood samples using a hematology analyzer instrument (BC-6900; Mindray, Shenzhen, China). In addition, the concentrations of serum glucose and CRP were determined in peripheral blood samples using a clinical chemistry system (ADVIA 2400, Siemens, Munich, Germany) and anti-CHROMA laser fluorescence reader, respectively.

\section{Calculation of Sample Size}

The number of patients recruited in each group was based on the primary outcome, by testing the percentage of $\mathrm{PD}-1^{(+)} \mathrm{CD} 8^{(+)}$ $\mathrm{T}$ cells in a previous pilot study. According to these pilot data, the difference in mean PD- ${ }^{(+)} \mathrm{CD} 8^{(+)} \mathrm{T}$ cell percentages between the 2 groups was $2.08 \%$, with a pooled SD of $2.57 \%$. To detect a difference of this magnitude between study groups, 32 patients were required in each group to provide $90 \%$ power at an alpha of 0.05 . However, considering a loss-to-follow-up rate of approximately $10 \%$ in our study, we aimed to enroll a total of 70 patients.

\section{Statistical Analyses}

The Shapiro-Wilk test was applied to assess the normality of continuous data. Normally distributed continuous data are presented as means (SD) and were analyzed using an independent Student $t$ test. Skewed data are presented as medians (interquartile range) and were compared using a Mann-Whitney U test or Wilcoxon rank-sum test. Categorical variables are reported as frequencies and were compared using a chi-square or Fisher's exact test. Changes in the percentages of $\mathrm{PD}-1^{(+)} \mathrm{CD} 8^{(+)}$or PD- $1^{(+)} \mathrm{CD} 4^{(+)}$ $\mathrm{T}$ cells and concentrations of inflammatory markers were calculated between baseline values at $\mathrm{T}_{0}$ and those at $\mathrm{T}_{1}, \mathrm{~T}_{2}$, and $\mathrm{T}_{3}$. Changes in both groups were analyzed using a mixed linear regression model, adjusted for age and ASA status (i.e., a random effect was introduced in an effort to account for repeated measures), in order to confirm the findings of the univariable analyses. In our model, study group and time were applied as predictors, interactions between the study group and time as fixed effects, and the patient as a random effect. An interaction term was taken into account to test whether the change over time was different between groups. In the univariable analyses, a Bonferroni correction was applied to post hoc analyses comparing changes over time. In addition, sensitivity analysis using a linear mixed model, with scale identity correlation matrices, was applied to confirm major differences between groups. All statistical analyses were performed using SPSS 19.0 software (IBM, Armonk, NY, USA), and $p$ values $<0.05$ were considered to indicate statistical significance.

Flurbiprofen Treatment Alters Immune Checkpoint Expression

\section{Results}

\section{Study Population}

The CONSORT diagram is shown in Figure 2. A total of 70 patients were screened for our study, with 68 patients ultimately participating. Of the 2 patients who were not included, one refused to participate and one did not satisfy the inclusion criteria. Four patients ( 2 in the flurbiprofen group, 2 in the control group) were withdrawn from the statistical analysis, despite being randomized into study groups. In the flurbiprofen group, one of these patients refused phlebotomy for laboratory testing after the operation, and one patient was withdrawn because of blood loss $>1.5 \mathrm{~L}$. Both patients in the control group withdrew due to tumor metastasis into the pleura, not having undergone a lung parenchyma resection procedure. Baseline and intraoperative characteristics of patients in both groups are shown in online supplementary Table 1 (see www.karger.com/doi/10.1159/000503166. No significant differences in age, body mass index, gender, or ASA status were observed between groups. There were also no significant between-group differences in surgery type, duration of surgery, the use of antibiotics, or intraoperative propofol consumption. Remifentanyl consumption was higher in the control group than in the flurbiprofen group. Outcome values are shown in Table 1. There were no significant differences in the percentages of $\mathrm{PD}$ $1^{(+)} \mathrm{CD}^{(+)} \mathrm{T}$ cells, $\mathrm{PD}-1^{(+)} \mathrm{CD} 4^{(+)} \mathrm{T}$ cells, or T lymphocyte subsets or inflammatory marker concentrations between groups at baseline and 1 week after surgery (data not shown).

\section{Outcomes}

As shown in Table 2, the increases in the percentage of PD- ${ }^{(+)} \mathrm{CD}^{(+)} \mathrm{T}$ cells observed $24 \mathrm{~h}\left(\mathrm{~T}_{1}\right)$ and $72 \mathrm{~h}$ postoperatively $\left(\mathrm{T}_{2}\right)$ in the control group were higher than those in the flurbiprofen group $\left(\mathrm{T}_{1}, 12.91 \pm 1.65 \mathrm{vs} .7 .86\right.$ $\pm 5.71 \%, p=0.031 ; \mathrm{T}_{2}, 11.54 \pm 1.54$ vs. $8.75 \pm 1.73 \%, p=$ $0.004)$. Original images of $\mathrm{PD}-1^{(+)} \mathrm{CD} 8^{(+)} \mathrm{T}$ cells at different time points are shown in Figure 1b. No differences were observed in the change in the percentage of PD- ${ }^{(+)} \mathrm{CD}^{(+)} \mathrm{T}$ cells at $\mathrm{T}_{1}$ and $\mathrm{T}_{2}$ between the groups. However, changes in the percentages of PD- $1^{(+)} \mathrm{CD} 8^{(+)} \mathrm{T}$ cells and $\mathrm{PD}-1^{(+)} \mathrm{CD} 4^{(+)} \mathrm{T}$ cells from baseline $\left(\mathrm{T}_{0}\right)$ were similar between groups 1 week after surgery $\left(\mathrm{T}_{3}\right.$; data not shown). Moreover, the decreases observed for all lymphocyte subsets at $T_{1}$ and $T_{2}$ were markedly greater in the control group than in the flurbiprofen group, with the exception of $\mathrm{CD} 8^{(+)} \mathrm{T}$ cells, which showed a significant change only at $\mathrm{T}_{1}$. In addition, the significant increases 


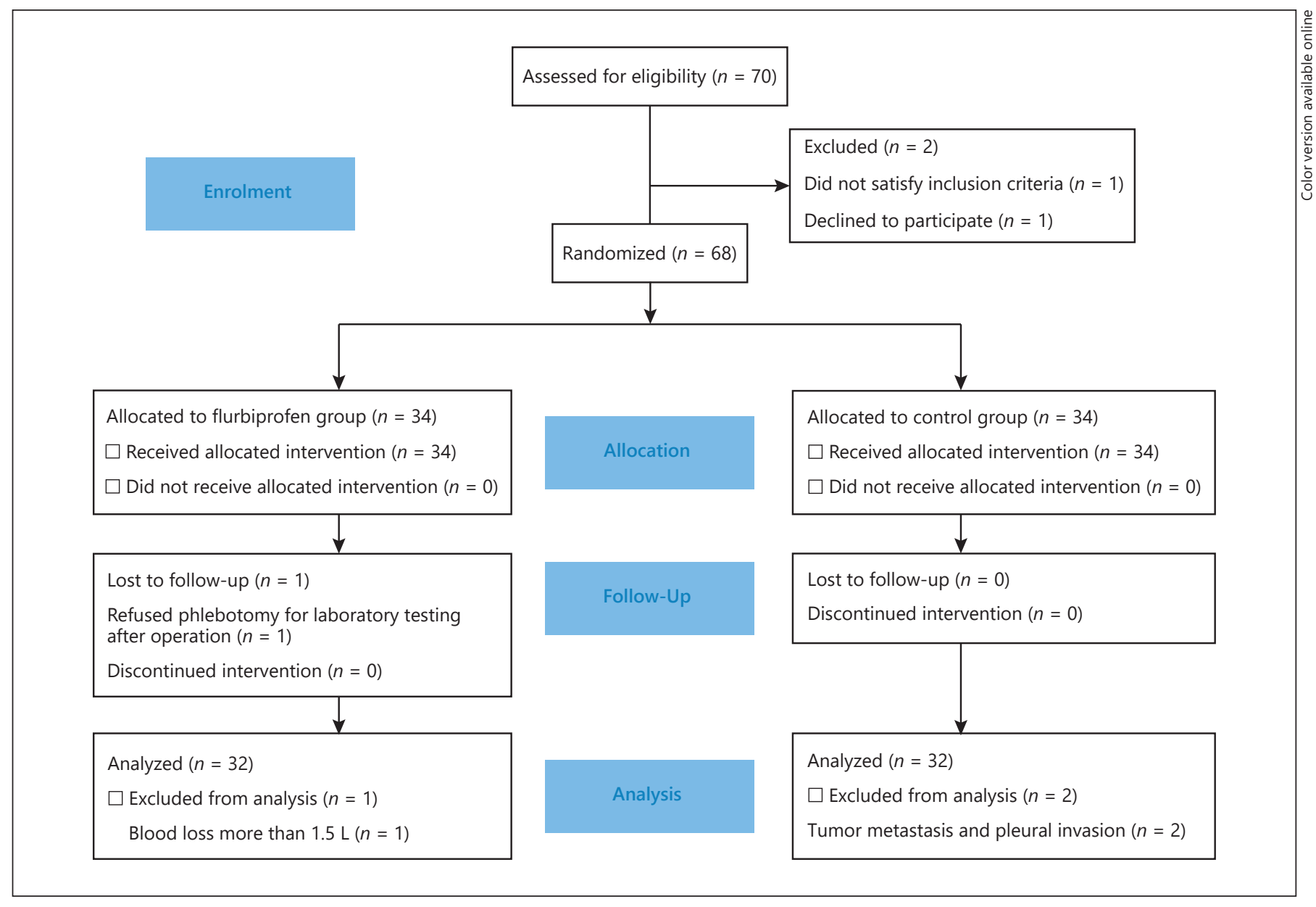

Fig. 2. CONSORT diagram of the trial process.

observed in the concentrations of TNF- $\alpha$, IFN- $\gamma$, IL- 6 , and CRP at $T_{1}$ and $T_{2}$ were greater in the control group than in the flurbiprofen group. At a longer postoperative follow-up period $\left(\mathrm{T}_{3}\right)$, no significant differences were observed in the abovementioned data from baseline (data not shown). Samples were also collected 3 weeks $\left(\mathrm{T}_{4}\right)$ after surgery; however, at this time point, there were no significant differences in the concentration of these inflammatory markers between groups (data not shown). Figure $1 \mathrm{~b}$ shows the expression of $\mathrm{PD}-1^{(+)}$on $\mathrm{CD} 8^{(+)} \mathrm{T}$ cells in 2 groups at $\mathrm{T}_{4}$.

There were no significant differences between groups with respect to the proportion of patients who were unexpectedly subjected to respiratory depression after surgery. Respiratory depression was defined as a respiratory rate $<8$ breaths per minute and oxygen saturation either below $92 \%$ or showing a decrease of $>5 \%$ from baseline in patients with a baseline $\mathrm{SPO}_{2}<90 \%$ [21]. There were also no significant between-group differences in the incidence of nausea or skin pruritus. Eight patients in the control group experienced vomiting and retching, compared with 1 patient in the flurbiprofen group $(p=0.026)$. Furthermore, the use of antiemetics in the control group was higher than that in the flurbiprofen group $(p=0.011)$. A significant reduction in score for cough was observed in the flurbiprofen group $24 \mathrm{~h}$ postoperatively, but no difference was observed between groups $72 \mathrm{~h}$ postoperatively. Moreover, 10 patients in the control group required postoperative rescue analgesia (tramadol) for unbearable pain, compared to three patients in the flurbiprofen group $(p=0.030)$. In addition, no differences were observed between the groups in terms of postoperative wound infection or the length of hospital stay. 
Table 1. Differences in perioperative PD-1 expression on $\mathrm{CD} 4^{(+)}$and $\mathrm{CD} 8^{(+)} \mathrm{T}$-cells and other inflammation and immune markers between the flurbiprofen and control groups

\begin{tabular}{|c|c|c|c|c|}
\hline Variable & $\begin{array}{l}\text { Control group } \\
(n=32)\end{array}$ & $\begin{array}{l}\text { Flurbiprofen group } \\
(n=32)\end{array}$ & $\begin{array}{l}\text { Difference } \\
(95 \% \mathrm{CI})\end{array}$ & $p$ value \\
\hline \multicolumn{5}{|l|}{$24 \mathrm{~h}$ after surgery } \\
\hline $\mathrm{PD}-1^{(+)}$on $\mathrm{CD} 4^{(+)} \mathrm{T}$-cells & $15.74(3.41)$ & $18.06(4.56)$ & $-2.33(-6.64$ to 1.99$)$ & 0.268 \\
\hline $\mathrm{PD}-1^{(+)}$on $\mathrm{CD} 8^{(+)} \mathrm{T}$-cells & $22.68(1.67)$ & $16.85(6.83)$ & $5.83(0.50$ to 11.16$)$ & 0.034 \\
\hline $\mathrm{CD}^{(+)} \mathrm{T}$-cells & $33.50(7.27)$ & $45.38(5.48)$ & $-11.88(-18.78$ to -4.97$)$ & 0.002 \\
\hline $\mathrm{CD} 4^{(+)} \mathrm{T}$-cells & $27.25(3.73)$ & $32.00(4.78)$ & $-4.75(-9.35$ to -0.15$)$ & 0.044 \\
\hline $\mathrm{CD}^{(+)} \mathrm{T}$-cells & $14.13(1.25)$ & $17.13(3.00)$ & $-3.00(-5.58$ to -0.42$)$ & 0.027 \\
\hline CD4:CD8 ratio & $0.74(0.19)$ & $1.16(0.34)$ & $-0.43(-0.72$ to -0.13$)$ & 0.008 \\
\hline NK cells & $7.58(0.78)$ & $10.04(0.93)$ & $-2.46(-3.39$ to -1.54$)$ & $<0.001$ \\
\hline Platelet count, $10^{9} / \mathrm{L}$ & $228.75(60.07)$ & $215.25(56.74)$ & $13.50(-49.16$ to 76.16$)$ & 0.651 \\
\hline Total WBC count, $10^{9} / \mathrm{L}$ & $12.85(2.32)$ & $12.44(1.40)$ & $0.41(-1.65$ to 2.47$)$ & 0.674 \\
\hline Hemoglobin, g/L & $120.25(8.23)$ & $121.63(6.63)$ & $-1.38(-9.39$ to 6.64$)$ & 0.718 \\
\hline Neutrophil count, $10^{9} / \mathrm{L}$ & $12.01(3.38)$ & $13.20(3.32)$ & $-1.19(-4.78$ to 2.41$)$ & 0.490 \\
\hline Lymphocyte count, $10^{9} / \mathrm{L}$ & $0.84(0.32)$ & $0.95(0.27)$ & $-0.11(-0.43$ to 0.20$)$ & 0.453 \\
\hline Monocyte count, $10^{9} / \mathrm{L}$ & $0.66(0.10)$ & $0.62(0.17)$ & $0.04(-0.11$ to 0.18$)$ & 0.622 \\
\hline Eosinophil count, $10^{9} / \mathrm{L}$ & $0.183(0.157)$ & $0.114(0.099)$ & $0.069(-0.074$ to 0.212$)$ & 0.315 \\
\hline Basophil count, $10^{9} / \mathrm{L}$ & $0.010(0.011)$ & $0.011(0.008)$ & $-0.001(-0.012$ to 0.009$)$ & 0.798 \\
\hline TNF- $\alpha, p g / m L$ & $1,680.13(273.48)$ & $1,350.38(283.36)$ & $329.75(31.13$ to 628.37$)$ & 0.033 \\
\hline IFN- $\gamma, \mathrm{pg} / \mathrm{mL}$ & $44.16(3.48)$ & $36.71(4.99)$ & $7.45(2.84$ to 12.06$)$ & 0.004 \\
\hline IL-6, pg/ mL & $178.38(13.17)$ & $145.50(20.33)$ & $32.88(14.51$ to 51.24$)$ & 0.002 \\
\hline $\mathrm{CRP}, \mathrm{mg} / \mathrm{L}$ & $44.11(13.46)$ & $16.74(3.00)$ & $27.38(16.05$ to 38.70$)$ & 0.001 \\
\hline Serum glucose, $\mathrm{mmol} / \mathrm{L}$ & $7.78(1.22)$ & $7.25(1.12)$ & $0.53(-0.73$ to 1.78$)$ & 0.384 \\
\hline \multicolumn{5}{|l|}{$72 \mathrm{~h}$ after surgery } \\
\hline $\mathrm{PD}-1^{(+)}$on $\mathrm{CD} 4^{(+)} \mathrm{T}$-cells & $15.13(2.87)$ & $18.39(4.64)$ & $-3.26(-7.40$ to 0.87$)$ & 0.113 \\
\hline $\mathrm{PD}-1^{(+)}$on $\mathrm{CD} 8^{(+)} \mathrm{T}$-cells & $21.31(1.45)$ & $17.74(3.69)$ & $3.57(0.57$ to 6.58$)$ & 0.023 \\
\hline $\mathrm{CD}^{(+)} \mathrm{T}$-cells & $33.88(3.87)$ & $43.50(7.71)$ & $-9.63(-16.17$ to -3.08$)$ & 0.007 \\
\hline $\mathrm{CD} 4^{(+)} \mathrm{T}$-cells & $20.88(2.80)$ & $28.38(4.81)$ & $-7.50(-11.72$ to -3.28$)$ & 0.002 \\
\hline $\mathrm{CD}^{(+)} \mathrm{T}$-cells & $15.88(1.81)$ & $17.0(2.0)$ & $-1.13(-3.17$ to 0.92$)$ & 0.258 \\
\hline CD4:CD8 ratio & $0.86(0.36)$ & $1.39(0.37)$ & $-0.53(-0.92$ to -0.13$)$ & 0.012 \\
\hline NK cells & $7.29(0.80)$ & $9.12(1.26)$ & $-1.84(-2.97$ to -0.71$)$ & 0.004 \\
\hline Platelet count, $10^{9} / \mathrm{L}$ & $232.38(75.64)$ & $209.50(71.30)$ & $22.88(-55.95$ to 101.70$)$ & 0.544 \\
\hline Total WBC count, $10^{9} / \mathrm{L}$ & $9.60(2.59)$ & $8.74(1.06)$ & $0.86(-1.36$ to 3.09$)$ & 0.405 \\
\hline Hemoglobin, $g / L$ & $125.25(5.73)$ & $122.25(4.27)$ & $3.0(-2.42$ to 8.42$)$ & 0.255 \\
\hline Neutrophil count, $10^{9} / \mathrm{L}$ & $6.20(1.13)$ & $6.28(2.43)$ & $-0.08(-2.11$ to 1.96$)$ & 0.938 \\
\hline Lymphocyte count, $10^{9} / \mathrm{L}$ & $0.95(0.26)$ & $1.13(0.27)$ & $-0.18(-0.46$ to 0.11$)$ & 0.206 \\
\hline Monocyte count, $10^{9} / \mathrm{L}$ & $0.55(0.09)$ & $0.47(0.16)$ & $0.09(-0.05$ to 0.22$)$ & 0.210 \\
\hline Eosinophil count, $10^{9} / \mathrm{L}$ & $0.115(0.068)$ & $0.086(0.022)$ & $0.029(-0.029$ to 0.086$)$ & 0.284 \\
\hline Basophil count, $10^{9} / \mathrm{L}$ & $0.018(0.010)$ & $0.021(0.016)$ & $-0.004(-0.018$ to 0.011$)$ & 0.593 \\
\hline TNF- $\alpha, p g / m L$ & $1,611.00(298.82)$ & $1,221.13(187.55)$ & $389.88(122.35$ to 657.41$)$ & 0.007 \\
\hline IFN- $\gamma, p g / m L$ & $41.43(2.50)$ & $35.25(3.90)$ & $6.18(2.66$ to 9.69$)$ & 0.002 \\
\hline $\mathrm{IL}-6, \mathrm{pg} / \mathrm{mL}$ & $160.38(8.18)$ & $137.00(14.84)$ & $23.38(10.53$ to 36.22$)$ & 0.002 \\
\hline $\mathrm{CRP}, \mathrm{mg} / \mathrm{L}$ & $48.68(10.67)$ & $24.55(9.52)$ & $24.13(13.28$ to 34.97$)$ & $<0.001$ \\
\hline Serum glucose, $\mathrm{mmol} / \mathrm{L}$ & $6.36(1.14)$ & $5.58(0.47)$ & $0.79(-0.15$ to 1.72$)$ & 0.092 \\
\hline
\end{tabular}

Data are presented as mean (SD) or median (IQR) and compared using an independent Student $t$ test or Mann-Whitney U test, respectively.

PD-1, programmed death 1; NK, natural killer; WBC, white blood cells; TNF- $\alpha$, tumor necrosis factor- $\alpha$; IFN- $\gamma$, interferon- $\gamma$; IL-6, interleukin-6; CRP, C-reactive protein; NA, not applicable; IQR, interquartile range. 
Table 2. Changes in perioperative $\mathrm{PD}-1^{(+)}$expression on $\mathrm{CD} 4^{(+)}$and $\mathrm{CD} 8^{(+)} \mathrm{T}$-cells and other inflammation and immune markers, after receiving flurbiprofen or placebo, at 24 and $72 \mathrm{~h}$ from the baseline values before induction of anesthesia

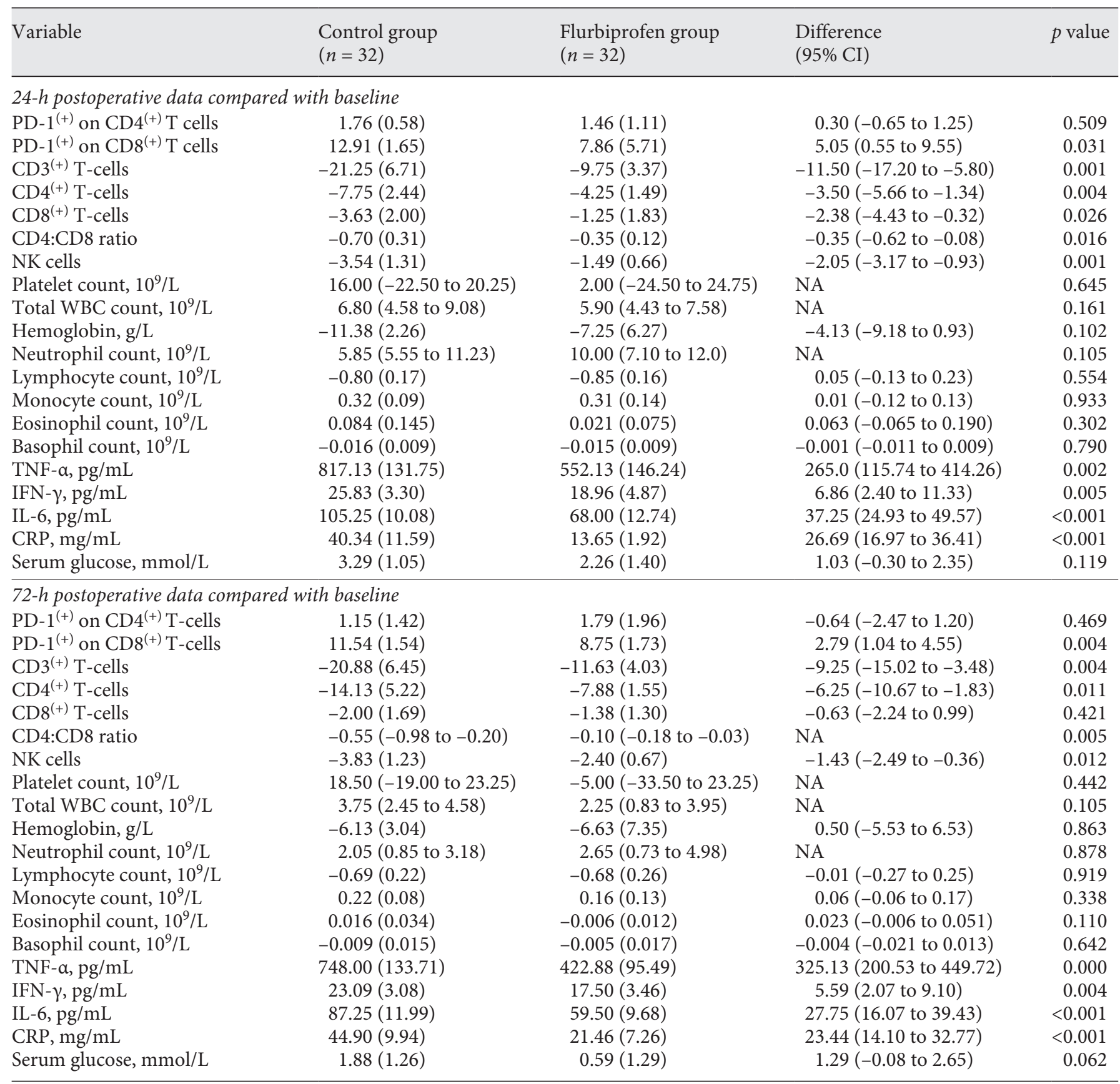

Data are presented as mean (SD) or median (IQR) and compared using an independent Student's $t$ test or Mann-Whitney U test, respectively.

PD-1, programmed death 1 ; NK, natural killer; WBC, white blood cells; TNF- $\alpha$, tumor necrosis factor- $\alpha$; IFN- $\gamma$, interferon- $\gamma$; IL-6, interleukin-6; CRP, C-reactive protein; NA, not applicable; IQR, interquartile range. 


\section{Sensitivity Analysis}

Linear mixed models confirmed the significant differences in the percentage of $\mathrm{CD} 8^{(+)} \mathrm{T}$ cells, $\mathrm{CD} 4^{(+)} \mathrm{T}$ cells expressing PD- $1^{(+)}$; the concentration of NK cells, TNF- $\alpha$, IL-6, and CRP between patients receiving flurbiprofen and those receiving placebo; and the significant differences observed at $\mathrm{T}_{1}$ and $\mathrm{T}_{2}$.

\section{Discussion}

PD-1, expressed in tumor-infiltrating T cells and circulating $\mathrm{T}$ cells, has been shown to predict prognosis and serve as a candidate therapeutic target in several malignant tumors, including NSCLC $[8,12,13,16]$. Recent evidence indicates that a higher level of PD- 1 on circulating $\mathrm{CD} 8^{(+)} \mathrm{T}$ cells in peripheral blood is correlated with poorer clinical outcome and shorter overall survival time [10]. In addition, recent clinical studies have shown that treatment with the PD-1 monoclonal antibody, Nivolumab, resulted in improved overall survival among NSCLC patients and cancer patients who improved significantly after receiving immune-checkpoint blockade therapy [22]. Despite the preclinical and clinical progress in immune-checkpoint blockade therapy for cancer, it remains unclear whether the perioperative use of analgesic drugs has a direct impact on these key inhibitory molecules during surgery. Interestingly, it is had been reported that COX inhibitors act synergistically with immunecheckpoint blockade therapy, implying that NSAIDs commonly used as perioperative analgesics may be a useful adjuvant for anti-PD-1/anti-CTLA-4 therapies in cancer patients [19]. To the best of our knowledge, this is the first clinical study providing direct evidence that NSAIDs alter the postoperative levels of PD-1, thus inhibiting the increase in $\mathrm{PD}-1$ expression on $\mathrm{CD} 8^{(+)} \mathrm{T}$ cells in the peripheral blood of lung cancer patients undergoing resection surgery.

Numerous studies have demonstrated that PD- 1 and CTLA-4 have distinct cellular mechanisms for attenuating $\mathrm{T}$ cell activation [14, 23-25]. Anti-PD-1 predominantly induces expansion of tumor-infiltrating exhausted-like $\mathrm{CD} 8^{(+)} \mathrm{T}$ cells, whereas anti-CTLA-4 engages both subsets of the $\mathrm{ICOS}^{(+)} \mathrm{Th} 1$-like $\mathrm{CD} 4^{(+)}$effector population and exhausted-like $\mathrm{CD} 8^{(+)} \mathrm{T}$ cells in the tumor microenvironment [26]. Furthermore, PD-1 and CTLA4 are detected in peripheral blood samples under different conditions. Although both markers are constitutively expressed on lymphocytes, only $\mathrm{PD}-1$ is usually detectable without any $\mathrm{T}$ cell stimulation in the majority of patients.
By contrast, CTLA-4 is rarely expressed on peripheral blood T cells, except under certain conditions of stimulation [27]. While tumor-infiltrating lymphocytes collected by tumor biopsy offer intuitive and fundamental perspectives on the immune response for tumor site analysis, analyses of circulating lymphocytes are easier to perform, can be repeated at several time points, and may provide a more systemic view of the immune response, especially in patients with visceral tumors. Peripheral blood analysis has recently provided insights into the changes in PD-1 levels in circulating $\mathrm{T}$ cells after immunotherapy. Therefore, we collected peripheral blood and examined the changes in postoperative PD-1 levels in circulating $\mathrm{T}$ cells.

Based on the results of our pilot study, $\mathrm{CD} 4^{(+)}$and $\mathrm{CD} 8^{(+)} \mathrm{T}$ cells in the peripheral blood of NSCLC patients generally have an exhausted phenotype and express higher levels of PD-1 than those of healthy subjects (NSCLC patients versus healthy volunteers; PD $-1^{(+)} \mathrm{CD}^{(+)} \mathrm{T}$ cell: $9.76 \pm 0.67$ vs. $8.61 \pm 0.98 \%, p=$ 0.016 ; $\mathrm{PD}-1^{(+)} \mathrm{CD} 4^{(+)} \mathrm{T}$ cell: $16.60 \pm 5.20$ vs. $10.40 \pm$ $1.37 \%, p=0.012$ ). COX activity and COX-dependent inflammatory mediators, such as PGs, facilitate the increase in the inhibitory immune-checkpoints, PD-1/ CTLA- 4 and low levels of PD-1/CTLA- 4 have been demonstrated in COX-2 ${ }^{\mathrm{MEC}}$ knock-out mice bearing tumors, suggesting that COX activity and downstream PGs are potentially linked with PD-1 [18]. Although NSAIDs may cooperate with anti-PD-1 blockade in inducing the eradication of tumors in preclinical studies [19], our study primarily demonstrated that flurbiprofen altered PD-1 levels on the circulating $\mathrm{CD} 8^{(+)} \mathrm{T}$ cell population in NSCLC patients up to $72 \mathrm{~h}$ postoperatively, without any change in the percentage of circulating PD- $1^{(+)} \mathrm{CD} 8^{(+)}$ $\mathrm{T}$ cells observed after that time point. Flurbiprofen administration during the perioperative period had little influence on the postoperative percentage of $\mathrm{PD}$ $1^{(+)} \mathrm{CD} 4^{(+)} \mathrm{T}$ cells. The percentage of lymphocytes after surgery in the control and flurbiprofen groups was, in general, lower compared with hospital reference values. It is interesting to note that there were extensive changes in lymphocyte subsets and inflammatory markers following administration of flurbiprofen in the short-term postoperative period up to $72 \mathrm{~h}$.

A possible explanation for the observed differences between groups is that prominent tumor-sustaining inflammatory factors are potent inducers of PD-1/CTLA-4. This indicates that the levels of PD-1 and other inhibitory checkpoints involved in $\mathrm{CD} 8^{(+)} \mathrm{T}$ cell exhaustion were markedly enhanced, with high levels of VEGF produced 
by a proangiogenic factor in the tumor microenvironment [28]. Moreover, COX-derived PGE2 promotes tumor progression by sustaining angiogenesis through the induction of VEGF. This is largely required for a stable blood supply to facilitate tumor growth $[29,30]$. We speculate that the inhibition of COX and PGE2 by flurbiprofen attenuated the increase in PD-1 levels, partly by abrogating the induction of VEGF.

There are several limitations of this study. First, further studies are needed to determine the exact mechanism by which NSAIDs downregulates antitumor immunity and immune escape. Second, although the randomization of participants in our study was strict, some baseline and perioperative factors were not equal between the 2 groups. Third, we did not subdivide CD $4^{(+)} \mathrm{T}$ cells into conventional $\mathrm{CD} 4^{(+)} \mathrm{T}$ cell and regulatory $\mathrm{CD} 4^{(+)} \mathrm{T}$ cell categories. Fourth, our study is a single-center investigation. A large multicenter study would be ideal to confirm our findings. Last, we have not investigated whether perioperative flurbiprofen administration affected the clinical outcome and overall survival of patients after leaving the hospital.

\section{Conclusions}

Perioperative administration of flurbiprofen attenuates the increase in levels of PD-1 on $\mathrm{CD}^{(+)} \mathrm{T}$ cells up to $72 \mathrm{~h}$ postoperatively, with no effect identified after this time.

\section{Acknowledgments}

This research was supported by the National Natural Science Foundation of China (No. 81503080), the Anhui Provincial Natural Science Foundation (No. 1608085QH210), the Anhui Provincial Key Research and Development Project Foundation (No. 1804h08020286), and a Clinical Research Grant from the $\mathrm{Wu}$ Jieping Medical Foundation (No. 320.6750.16166). The authors acknowledge the assistance of ChenCheng Xu and XiaoDong Pan, Department of Thoracic Surgery, Anhui Provincial Hospital, for taking venous blood samples for laboratory testing.

\section{Disclosure Statement}

The authors have no conflicts of interest to declare.

\section{References}

1 Garon EB, Rizvi NA, Hui R, Leighl N, Balmanoukian AS, Eder JP, et al.; KEYNOTE-001 Investigators. Pembrolizumab for the treatment of non-small-cell lung cancer. N Engl J Med. 2015 May;372(21):2018-28.

2 Cheng TY, Cramb SM, Baade PD, Youlden DR, Nwogu C, Reid ME. The international epidemiology of lung cancer: latest trends, disparities, and tumor characteristics. J Thorac Oncol. 2016 Oct;11(10):1653-71.

3 Reck M, Heigener DF, Mok T, Soria JC, Rabe KF. Management of non-small-cell lung cancer: recent developments. Lancet. 2013 Aug; 382(9893):709-19.

4 Odorizzi PM, Pauken KE, Paley MA, Sharpe A, Wherry EJ. Genetic absence of PD-1 promotes accumulation of terminally differentiated exhausted CD8+ T cells. J Exp Med. 2015 Jun;212(7):1125-37.

5 Lingel H, Wissing J, Arra A, Schanze D, Lienenklaus S, Klawonn F, et al. CTLA-4-mediated posttranslational modifications direct cytotoxic T-lymphocyte differentiation. Cell Death Differ. 2017 Oct;24(10):1739-49.

6 Keir ME, Butte MJ, Freeman GJ, Sharpe AH. PD- 1 and its ligands in tolerance and immunity. Annu Rev Immunol. 2008;26(1):677704.

7 Hahn AW, Gill DM, Pal SK, Agarwal N. The future of immune checkpoint cancer therapy after PD-1 and CTLA-4. Immunotherapy. 2017 Jun;9(8):681-92.
8 Boussiotis VA. Molecular and biochemical aspects of the PD-1 checkpoint pathway. N Engl J Med. 2016 Nov;375(18):1767-78.

9 Zheng H, Liu X, Zhang J, Rice SJ, Wagman M, Kong Y, et al. Expression of PD-1 on CD4+ T cells in peripheral blood associates with poor clinical outcome in non-small cell lung cancer. Oncotarget. 2016 Aug;7(35):56233-40.

10 Waki K, Yamada T, Yoshiyama K, Terazaki Y, Sakamoto S, Matsueda S, et al. PD-1 expression on peripheral blood T-cell subsets correlates with prognosis in non-small cell lung cancer. Cancer Sci. 2014 Oct;105(10):122935.

11 Brahmer J, Reckamp KL, Baas P, Crinò L, Eberhardt WE, Poddubskaya E, et al. Nivolumab versus docetaxel in advanced squamous-cell non-small-cell lung cancer. N Engl J Med. 2015 Jul;373(2):123-35.

12 Wolchok JD, Kluger H, Callahan MK, Postow MA, Rizvi NA, Lesokhin AM, et al. Nivolumab plus ipilimumab in advanced melanoma. $\mathrm{N}$ Engl J Med. 2013 Jul;369(2):122-33.

13 Topalian SL, Hodi FS, Brahmer JR, Gettinger SN, Smith DC, McDermott DF, et al. Safety, activity, and immune correlates of anti-PD-1 antibody in cancer. N Engl J Med. 2012 Jun; 366(26):2443-54.

14 Pardoll DM. The blockade of immune checkpoints in cancer immunotherapy. Nat Rev Cancer. 2012 Mar; 12(4):252-64.
15 Nghiem PT, Bhatia S, Lipson EJ, Kudchadkar RR, Miller NJ, Annamalai L, et al. PD-1 Blockade with pembrolizumab in advanced merkelcell carcinoma. N Engl J Med. 2016 Jun; 374(26):2542-52.

16 Larkin J, Chiarion-Sileni V, Gonzalez R, Grob JJ, Cowey CL, Lao CD, et al. Combined nivolumab and ipilimumab or monotherapy in untreated melanoma. N Engl J Med. 2015 Jul;373(1):23-34.

17 Chen JH, Perry CJ, Tsui YC, Staron MM, Parish IA, Dominguez CX, et al. Prostaglandin E2 and programmed cell death 1 signaling coordinately impair CTL function and survival during chronic viral infection. Nat Med. 2015 Apr;21(4):327-34

18 Markosyan N, Chen EP, Evans RA, Ndong V, Vonderheide RH, Smyth EM. Mammary carcinoma cell derived cyclooxygenase 2 suppresses tumor immune surveillance by enhancing intratumoral immune checkpoint activity. Breast Cancer Res. 2013;15(5):R75.

19 Zelenay S, van der Veen AG, Böttcher JP, Snelgrove KJ, Rogers N, Acton SE, et al. Cyclooxygenase-dependent tumor growth through evasion of immunity. Cell. 2015 Sep; 162(6):1257-70

20 Wang D, Yang XL, Chai XQ, Shu SH, Zhang XL, $\mathrm{Xie} \mathrm{YH}$, et al. A short-term increase of the postoperative naturally circulating dendritic cells subsets in flurbiprofen-treated patients with esophageal carcinoma undergoing thoracic surgery. Oncotarget. 2016 Apr;7(14):18705-12. 
21 Savelloni J, Gunter H, Lee KC, Hsu C, Yi C, Edmonds KP, et al. Risk of respiratory depression with opioids and concomitant gabapentinoids. J Pain Res. 2017 Nov; 10:2635-41.

22 Borghaei H, Paz-Ares L, Horn L, Spigel DR, Steins M, Ready NE, et al. Nivolumab versus docetaxel in advanced nonsquamous nonsmall-cell lung cancer. N Engl J Med. 2015 Oct;373(17):1627-39.

23 Walker LS, Sansom DM. The emerging role of CTLA4 as a cell-extrinsic regulator of T cell responses. Nat Rev Immunol. 2011 Nov; 11(12):852-63.
24 Chemnitz JM, Parry RV, Nichols KE, June $\mathrm{CH}$, Riley JL. SHP-1 and SHP-2 associate with immunoreceptor tyrosine-based switch motif of programmed death 1 upon primary human $\mathrm{T}$ cell stimulation, but only receptor ligation prevents T cell activation. J Immunol. 2004 Jul;173(2):945-54.

25 Krummel MF, Allison JP. CD28 and CTLA-4 have opposing effects on the response of $\mathrm{T}$ cells to stimulation. J Exp Med. 1995 Aug; 182(2):459-65.

26 Wei SC, Levine JH, Cogdill AP, Zhao Y, Anang NA, Andrews MC, et al. Distinct cellular mechanisms underlie anti-CTLA-4 and anti-PD-1 checkpoint blockade. Cell. 2017 Sep;170(6):1120-1133.e17.
27 Kamphorst AO, Pillai RN, Yang S, Nasti TH, Akondy RS, Wieland A, et al. Proliferation of PD-1+ CD8 T cells in peripheral blood after PD-1-targeted therapy in lung cancer patients. Proc Natl Acad Sci USA. 2017 May; 114(19):4993-8.

28 Voron T, Colussi O, Marcheteau E, Pernot S, Nizard M, Pointet AL, et al. VEGF-A modulates expression of inhibitory checkpoints on CD8+ T cells in tumors. J Exp Med. 2015 Feb; 212(2):139-48.

29 Tedore T. Regional anaesthesia and analgesia: relationship to cancer recurrence and survival. Br J Anaesth. 2015 Dec;115 Suppl 2:ii34-45.

30 Wang D, Dubois RN. Eicosanoids and cancer. Nat Rev Cancer. 2010 Mar;10(3):181-93. 